\title{
Structural Differences between Reaction Wood and Opposite Wood with Different Drying Temperatures
}

\author{
Ivan Klement, ${ }^{\mathrm{a}}$ Tatiana Vilkovská, ${ }^{\mathrm{a}, *}$ Peter Vilkovský, ${ }^{\mathrm{a}}$ and Štěpán Hýsek ${ }^{\mathrm{b}}$ \\ Reaction wood is characterized by having different anatomical and \\ chemical features than normal wood. The different composition of cell \\ walls, the higher quantitative proportion of thick-wall fiber cells, diameter, \\ and the abundance of vessels have remarkable effects on reaction wood's \\ physical and mechanical properties. Reaction wood has fewer vascular \\ cells. In addition, it has a smaller lumen diameter, which results in reduced \\ permeability. Therefore, reaction wood is more difficult to dry at a certain \\ moisture content. The differences in the drying times of the reaction wood \\ and the normal wood were largest at a temperature of $60^{\circ} \mathrm{C}$ and durations \\ greater than $30 \mathrm{~h}$, and the reaction wood dried more slowly. At a \\ temperature of $120^{\circ} \mathrm{C}$, the differences in drying time were minimalized, \\ and drying end times were almost identical. The expected negative effect \\ of higher temperature on the morphology of reaction wood and opposition \\ wood was not confirmed.
}

Keywords: G-layer; Reaction wood; Tension wood; Morphology of tension wood; Drying tension wood

Contact information: a: Department of Wood Technology, Faculty of Wood Sciences and Technology, Technical University in Zvolen, T. G. Masaryka 24, Zvolen, 96001 Slovakia; b: Department of Wood Processing and Biomaterials, Faculty of Forestry and Wood Sciences, Czech University of Life Sciences Prague, Kamýcká 129, 16500 Prague, Czech Republic;

*Corresponding author: tatiana.vilkovska@tuzvo.sk

\section{INTRODUCTION}

Beech wood (Fagus sylvatica L.) is the most common wood species in the Slovak Republic (Reinprecht 2016; Vilkovský and Čunderlík 2017). Reaction beech wood (tension wood) has different anatomical and chemical characteristics from normal or opposite wood. Tension wood is a defect in the structure of wood that develops during tree growth in the area of the trunk that is stressed by tension forces from different external factors (Okuyama et al. 1994; Kúdela and Čunderlík 2012). Reaction wood is a common defect in beech wood. Kúdela and Čunderlík (2012) reported a $14 \%$ to $21 \%$ proportion of reaction wood in beech wood. Due to the presence of reaction wood, deformations, higher proportions of waste, and lower final product yield occur. In fact, the difference in the drying rate curves of reaction wood and opposite wood gradually decreases when the drying process progresses to the bound water domain. The analysis of mass diffusivity and density in beech indicates that the diffusion of bound water is relatively easy in tension wood, which is consistent with the structure of the G-layer. The differences are noticeable in the microscopic structure of wood (Vilkovská et al. 2018). The different composition of cell walls and the higher quantitative proportion of thick-wall fiber cells, diameter, and the abundance of vessels have noticeable effects on the physical and mechanical properties of reaction wood (Meloche et al. 2006). Table 1 shows reported values of anatomical characteristics of tension and normal beech wood (Čunderlík and Hudec 2002).

Čunderlík and Hudec (2002) confirmed the presence of differences in vascular porosity of beech wood in different annual rings. The annual ring of normal wood had a vascular porosity of $30.3 \%$, and the annual ring with a high proportion of reaction wood 
had a vascular porosity of $19.9 \%$, which is almost $33 \%$ lower. This difference in the vascular porosities of normal and reaction wood considerably affected the permeability of beech wood in individual zones. The difference in the composition of the cell wall was particularly remarkable.

Table 1. Anatomical Characteristics of Tension Wood and Normal Wood (Fagus sylvatica L.) Čunderlík and Hudec (2002)

\begin{tabular}{|c|c|c|c|}
\hline & $\begin{array}{c}\text { Diameter of } \\
\text { Vessels }(\mu \mathrm{m})\end{array}$ & $\begin{array}{c}\text { Diameter Bordered Pits } \\
(\mu \mathrm{m})\end{array}$ & $\begin{array}{c}\text { Quantity of Vessels } \\
\left(\mathrm{mm}^{2}\right)\end{array}$ \\
\hline Tension Wood & $31.7 \pm 5.1$ & 3.5 to $4.3 \pm 0.8$ & 51 \\
\hline Normal Wood & $55.2 \pm 15.8$ & 4.9 to $6 \pm 1.1$ & 98 \\
\hline
\end{tabular}

Figure 1 shows the differences in the cell walls of normal wood and reaction wood. The secondary cell wall of normal wood consists of $S_{1}, S_{2}$, and $S_{3}$ layers, whereas the $S_{3}$ layer is replaced by a gelatinous layer (G-layer) in reaction wood. The G-layer is thicker than the $\mathrm{S}_{2}$ layer.

(a)

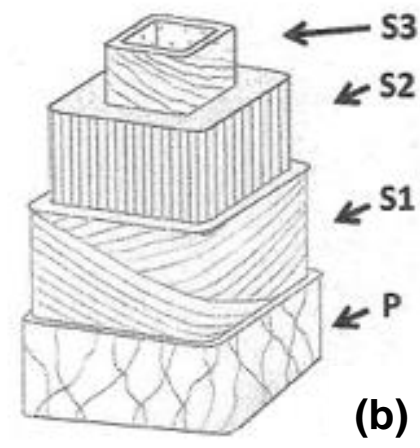

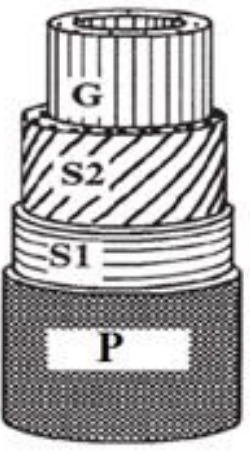

Fig. 1. The cell wall structure of normal wood (a) and tension wood (b) (Clair et al. 2006)

The G-layer has been the subject of number of studies (Norberg and Meier 1966; Araki et al. 1983; Clair et al. 2003, 2006; Kampf et al. 2017). These authors compared the chemical composition of normal wood with the chemical composition of the G-layer. Their results revealed that the G-layer is composed of a high portion of crystalline cellulose and it is non-lignified (Norberg and Meier 1966; Clair et al. 2003). Due to the parallel orientation of cellulosic microfibrils $\left(0^{\circ}\right.$ to $\left.5^{\circ}\right)$ with the cell axis and the absence of lignin, it is highly predisposed to high transverse shrinkage. This shrinkage in the drying process results in the separation of the G-layer from the outer layers of $S_{1}$ and $S_{2}$. Norberg and Meier (1966) report that the quality and quantity of the G-layer has considerable influence on reaction wood properties. Their analysis of the chemical composition of reaction wood found that tension wood consists mainly of crystalline cellulose (Norberg and Meier 1966). In addition, Čunderlík et al. (1995) stated that the composition of the cell wall and its microscopic and submicroscopic structure make it a strengthening matrix that is composed mostly of polymers, and the angle of microfibrils provides the necessary strength to increase the crystalline cellulose content. The shrinkage and swelling of tension wood is more prominent in the longitudinal direction, which results in higher values of longitudinal contraction Čunderlík et al. (1995).

Further, Norberg and Meier (1966) and Placet et al. (2006) investigated the higher longitudinal shrinkage of reaction wood, and their aim was to search for more pronounced differences in shrinkage in layers other than the G-layer. A more detailed explanation of 
tension wood's higher shrinkage in the longitudinal direction was reported by Čunderlík (1997) and Fang et al. (2008). The observation and analysis of the cell wall layer composition revealed that the G-layer is characterized by high transverse shrinkage. Because of this shrinkage and the weak bonds between the $G$ and $S_{2}$ layers, the G-layer separates from the $S_{2}$ layer. This separation allows the $S_{1}$ layer and the $S_{2}$ layer to shrink more in the transverse direction. The thickness of the G-layer in cell walls varies. Fang et al. (2008) found that the cell lumen size of reaction wood increased due to drying, but lumen size decreased for normal wood (Fig. 2).

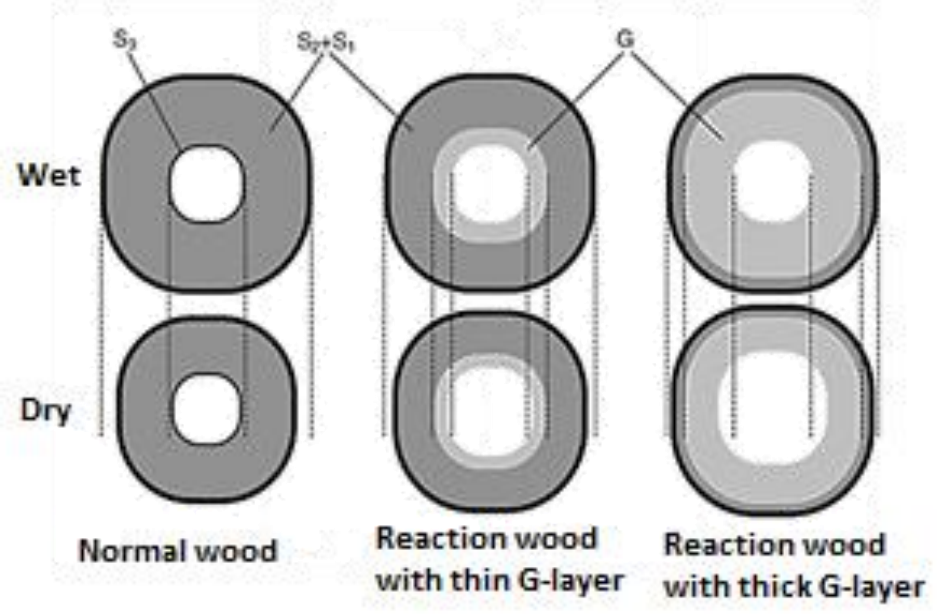

Fig. 2. The shrinkage patterns of normal and reaction wood (Fang et al. 2008)

Both the longitudinal shrinkage and volumetric shrinkage of reaction wood is higher. However, volumetric shrinkage is less sizable than shrinkage in the longitudinal direction. The nonlignified G-layer leads to easily deformable cell walls, which results in lower compression strength for the tension reaction wood (Placet et al. 2006; Fang et al. 2008).

The aim of this paper was to analyze the influence of temperature 60 and $120{ }^{\circ} \mathrm{C}$ on the structural differences of reaction and opposite wood.

\section{EXPERIMENTAL}

\section{Materials}

Beech logs were selected from the Michalková - Burzovo (550 m above sea level) forests of the University Forest Enterprise of the Technical University in Zvolen, Slovakia. The selection of suitable logs containing reaction wood was made by considering log curvature, the presence of exocentrically situated pith, the use of chemical reagents, and the pearlescent coloring of the cross-section after drying.

The selected beech logs had a diameter of $45 \pm 1 \mathrm{~cm}$ at the wide end and a length of $2 \mathrm{~m}$. The beech logs did not have red false heartwood or other visible defects that could negatively affect the measurement results.

Four beech logs were used for measurement. In the laboratory experiments, it was necessary to maintain the greatest match of properties between the two types of beech wood (reaction and opposite) compared. After identifying the reaction wood zone, two groups of samples containing reaction wood $\left(\mathrm{R}_{1}\right.$ and $\left.\mathrm{R}_{2}\right)$ and two groups of samples containing opposite wood $\left(\mathrm{O}_{1}\right.$ and $\left.\mathrm{O}_{2}\right)$ were cut from the zone (Fig. 3). 


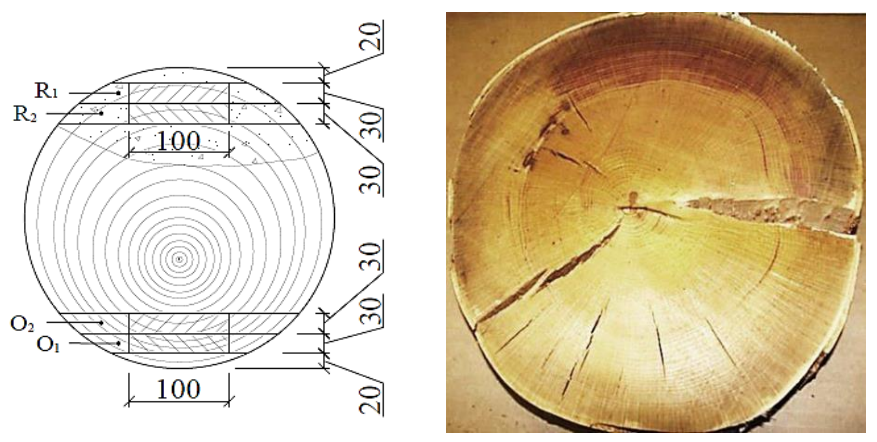

Fig. 3. The selection process of two groups of samples containing reaction wood $\left(R_{1}\right.$ and $\left.R_{2}\right)$ and two groups containing opposite wood $\left(\mathrm{O}_{1}\right.$ and $\left.\mathrm{O}_{2}\right)$; the dimensions of the drying samples were $100 \mathrm{~mm} \times 300 \mathrm{~mm} \times 30 \mathrm{~mm}(\mathrm{w} \times \mathrm{I} \times \mathrm{t})$

Opposite wood was located on the side opposite to the reaction wood on the cut discs (Fig. 3). The samples had a thickness of $30 \mathrm{~mm}$, a width of $100 \mathrm{~mm}$, and a length of $400 \mathrm{~mm}$. The fronts of the samples were treated with a chemical reagent (modified chlorozinc-iodine chemical reagent) from both sides by brush to allow clearer identification of the reaction wood (red color) in the sample (Fig. 4). Subsequently, the zone treated with the chemical reagent was cut $50 \mathrm{~mm}$ from each side before the drying process.

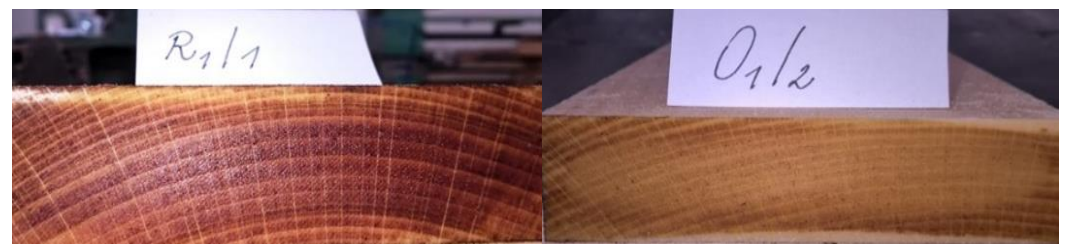

Fig. 4. The front of the samples were treated with chemical reagents

The samples were dried in a Memmert HCP 108 laboratory kiln (Memmert GmbH + Co. KG, Schwabach, Germany). The drying was conducted at temperatures of $60{ }^{\circ} \mathrm{C}$ and $120{ }^{\circ} \mathrm{C}$. Additional information about the drying mode is shown in Table 2. A constant flow velocity of the drying medium $\left(2 \pm 0.2 \mathrm{~m} \cdot \mathrm{s}^{-1}\right)$ was used for drying. Warm-air drying process was used by constant drying conditions above and under FSP temperature $60{ }^{\circ} \mathrm{C}$ and relative humidity $91 \pm 0.5 \%$.

The process of high temperature drying was divided into two phases. The first phase was heating, where the drying temperature was raised to $90{ }^{\circ} \mathrm{C}$ and the relative humidity was $94 \pm 0.5 \%$. These parameters were maintained in the first phase of the drying process until the moisture content in the samples did not decrease below the FSP (free water domain) approximately 30\%. After decreasing the moisture content below the fiber saturation point in both samples, the temperature of the dry bulb increased up to $120{ }^{\circ} \mathrm{C}$ and the relative humidity was without regulation (bound water domain). The last part of drying schedule was cooling to approximately $20{ }^{\circ} \mathrm{C}$. The moisture content (MC) was measurements on all the samples, both before and after the drying process, according the norm STN EN 49 0103. The average final moisture content was $10 \% \pm 2 \%$.

The oven-dry density was determined for every sample with reaction wood and opposite wood, and measurement was performed under laboratory conditions. The total number of samples was 32 pieces. The oven-dry density was calculated according to STN 490108 (1993). The preparation of samples for scanning electron microscopy was as follows; the $1 \times 1 \times 1 \mathrm{~cm}$ wood blocks from both opposite and reaction wood were immersed in water at $20^{\circ} \mathrm{C}$ for 7 days to soften the wood. In order to obtain a smooth section, the 
cross section was subsequently cut with a GSL1-microtome (Eidg. Forschungsanstalt WSL, Birmensdorf, Switzerland). Prepared samples were subsequently vacuum dried dusted with gold on a Q150R ES sputter (Quorum Technologies Ltd., Laughton, England). The prepared surface of the preparation was observed using a MIRA 3 electron microscope (Tescan Orsay Holding, Brno, Czech Republic). A secondary electron detector was used and an acceleration voltage of $15 \mathrm{kV}$, a working distance of $8 \mathrm{~mm}$, and a spot size of $4 \mathrm{~nm}$ were set. The exported images have not been modified in any way. Samples were taken at $50 \mu \mathrm{m}$ and $10 \mu \mathrm{m}$.

\section{RESULTS AND DISCUSSION}

The parameters of drying modes, average density, and moisture content are shown in Table 2, which also shows the values of drying time with different drying modes and samples.

Table 2. Parameter of Drying Modes (relative humidity, temperature, and drying time), MC and Density

\begin{tabular}{|c|c|c|c|c|c|c|}
\hline Samples & Drying Mode $\left({ }^{\circ} \mathrm{C}\right)$ & \multirow{4}{\varphi}{$\begin{array}{c}\varnothing \\
(\%)\end{array}$} & $\begin{array}{c}\varnothing \rho_{0} \\
\left(\mathrm{~kg} \cdot \mathrm{m}^{-3}\right)\end{array}$ & $\begin{array}{c}\text { MC } \\
\text { Before (\%) }\end{array}$ & $\begin{array}{c}\text { MC } \\
\text { After (\%) }\end{array}$ & $\tau(\mathrm{h})$ \\
\hline Reaction & 60 & \multirow{2}{*}{91} & 668 & 81.6 & 12.00 & 200 \\
\cline { 1 - 4 } Opposite & 60 & 662 & 82.7 & 10.44 & 170 \\
\hline Reaction & 120 & \multirow{2}{*}{94} & 659 & 80.3 & 9.77 & 165 \\
\cline { 1 - 4 } Opposite & 120 & 649 & 76.9 & 8.47 & 163 \\
\hline
\end{tabular}

MC: Moisture content; $\tau$ : drying time; $\varphi$ : relative humidity; $\varnothing \rho_{0}$ : average oven-dry density

The differences in drying times of the reaction wood and the opposite wood were most substantial at a temperature of $60^{\circ} \mathrm{C}$. The difference was approximately $30 \mathrm{~h}$, and the reaction wood dried more slowly. At $120^{\circ} \mathrm{C}$, the differences were equalized, and the drying end times were almost identical. One possible explanation could be that the nanostructure of the G-layer, which is mesoporous (contains pores between $2 \mathrm{~nm}$ and $50 \mathrm{~nm}$ in size), allowed the migration of bound water more easily at $120^{\circ} \mathrm{C}$. Different density values were measured in the oven dry-state of the reaction wood samples, and the values for reaction wood were higher than opposite wood samples. Variability of density in dry state can be caused by different quantitative and qualitative representations of thick-walled fibers in the gelatinous layer. Based on the results of Cunderlík (1997), the microscopic and chemical structure of the cell wall of tension wood is responsible for the differences in physical properties to those of opposite wood. The differences were also measured by Tarmian et al. (2012) and Pilate et al. (2004), who reported higher density values of approximately $5 \%$ to $10 \%$.

A $50 \mu \mathrm{m}$ sample of reaction wood at $60{ }^{\circ} \mathrm{C}$ is shown in Fig. 5. Reaction wood is typically composed of high fiber cells with a thick G-layer ratio, and more irregular peripheral and perpendicular cracks appear in the cell wall. The cells lumen is irregular and smaller, and cracks in the compound middle lamella are less visible in the reaction wood.

The results, which were in concordance with Čunderlík and Hudec (2002), showed that the non-lignified G-layer was likely to have deformable cell walls, which reduced the compressive tensile strength of reaction wood and irregular lumen. Microscopic observations found that reaction wood had fewer vascular cells. The smaller lumen 
diameter of reaction wood led to reduced permeability. Therefore, reaction wood is more difficult to dry at a certain moisture content.

This was also confirmed by the results of drying (Table 2), which found that the difference in the drying of reaction wood and opposite wood was most remarkable at 60 ${ }^{\circ} \mathrm{C}$. The cause of slower drying could have been the low porosity of the wood. The longer drying time of the tension wood during free water removal may have been associated with the specific bordered pith structure in the cell walls and its smaller diameters. At a $120{ }^{\circ} \mathrm{C}$ drying temperature, differences were less remarkable and almost equal.

The results suggest that bound water diffusion is relatively easy in the G-layer of tension wood. This could be due to the chemical composition of this layer, which consists mostly of cellulose and contains almost no lignin (Gardiner et al. 2014). The present observations are consistent with those of Vilkovská et al. (2018), who reported that the tension wood had a lower ratio of lignin to polysaccharides and a lower amount of hemicellulose than opposite (normal) wood. The cellulose in tension wood had a higher degree of crystallinity than that in normal wood.
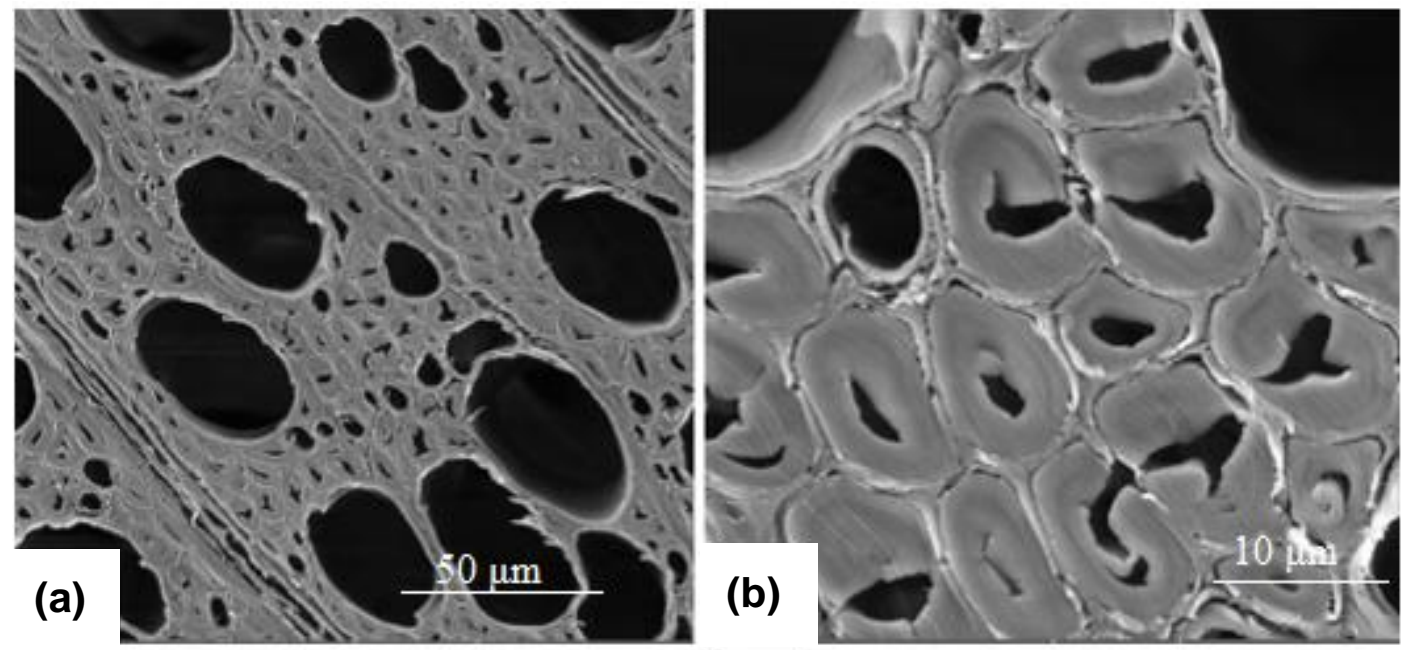

Fig. 5. Reaction wood at temperature $60^{\circ} \mathrm{C}: 50 \mu \mathrm{m}$ (a) and $10 \mu \mathrm{m}$ (b)

The results of this study provide support for other findings on this topic (Norberg and Meier 1966; Araki et al. 1983; Clair et al. 2003, 2006). These authors claim that due to the almost parallel orientation of the cellulose microfibrils $\left(0^{\circ}\right.$ to $\left.5^{\circ}\right)$ with the fibrous cell axis and the absence of lignin, reaction wood is expected to undergo large transversal shrinkages, which are cause of tearing the G-layer from the layer $\mathrm{S}_{2}$ in the drying process. By comparing images of reaction wood and opposite wood at a temperature of $60{ }^{\circ} \mathrm{C}$ and an identical scale of $50 \mu \mathrm{m}$, opposite wood (Fig. 5a) was found to have fewer fibrous cells (Norberg and Meier 1966; Araki et al. 1983; Clair et al. 2003, 2006).

Compared to the reaction wood, opposite wood had more vascular cells, which led to better liquid permeability and faster reaching of the required final moisture. Results are also in agreement with Tarmian et al. (2012), who reported that the proportion of vessels in reaction wood is $21.8 \%$ and that of opposite wood is $32.9 \%$. A temperature of $60{ }^{\circ} \mathrm{C}$ caused small drying cracks, but the cell wall structure was not excessively damaged. Figure $6 \mathrm{~b}$ shows the opposite wood at a $10 \mu \mathrm{m}$ scale, and thinner cell walls and larger lumens can be seen. The cracks are oriented mainly through the bordered pits.

A temperature of $120{ }^{\circ} \mathrm{C}$ was also used to compare the morphology of the reaction wood and opposite wood. Microscopic preparations of reaction wood are shown in Fig. 7. The reaction wood released drying stresses into the cell wall and G-layer but not into the composite middle lamella. The G-layer tore perpendicular to the perimeter of the cell, 
which was reflected in the irregular shape of the lumen. The negative effect of the higher temperature was not confirmed.
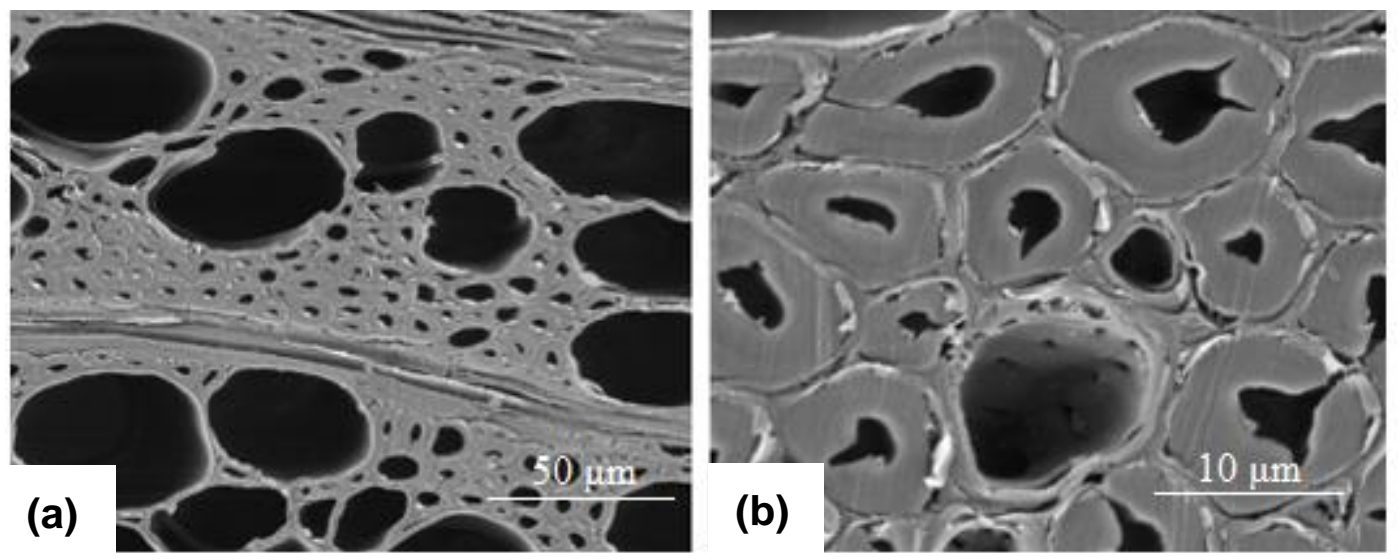

Fig. 6. Opposite wood at temperature $60^{\circ} \mathrm{C}: 50 \mu \mathrm{m}$ (a) and $10 \mu \mathrm{m}$ (b)
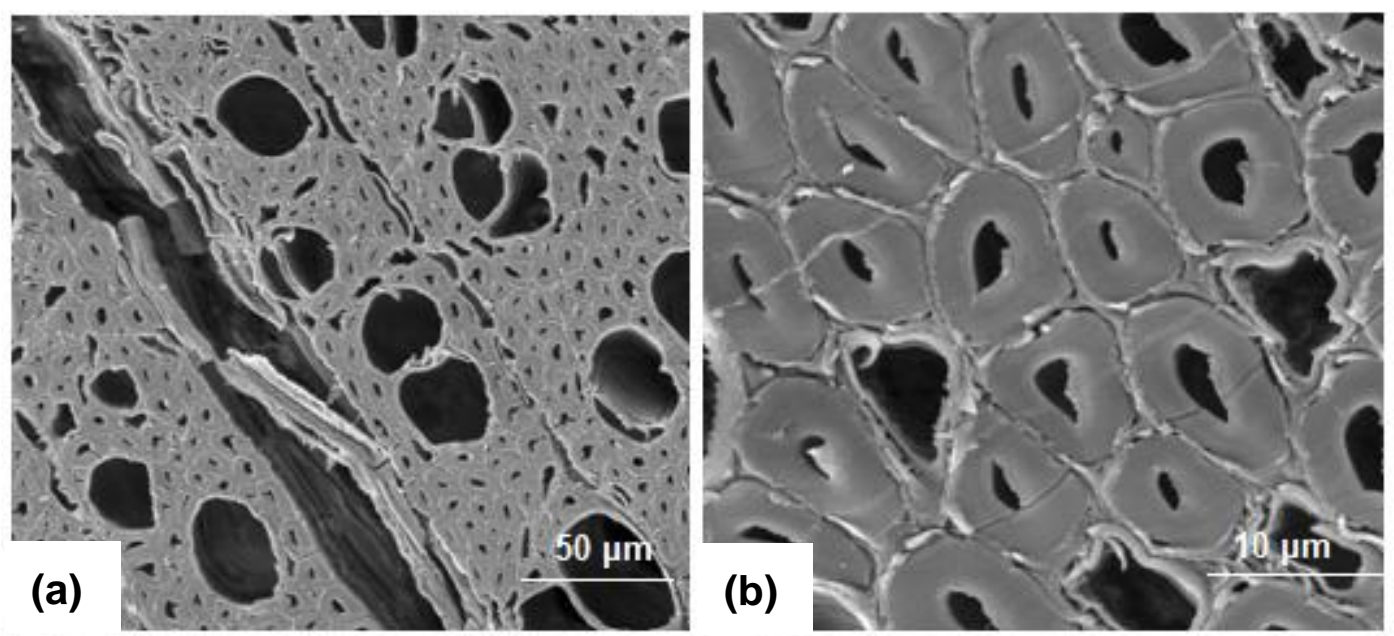

Fig. 7. Reaction wood at temperature $120^{\circ} \mathrm{C}: 50 \mu \mathrm{m}$ (a) and $10 \mu \mathrm{m}(\mathrm{b})$
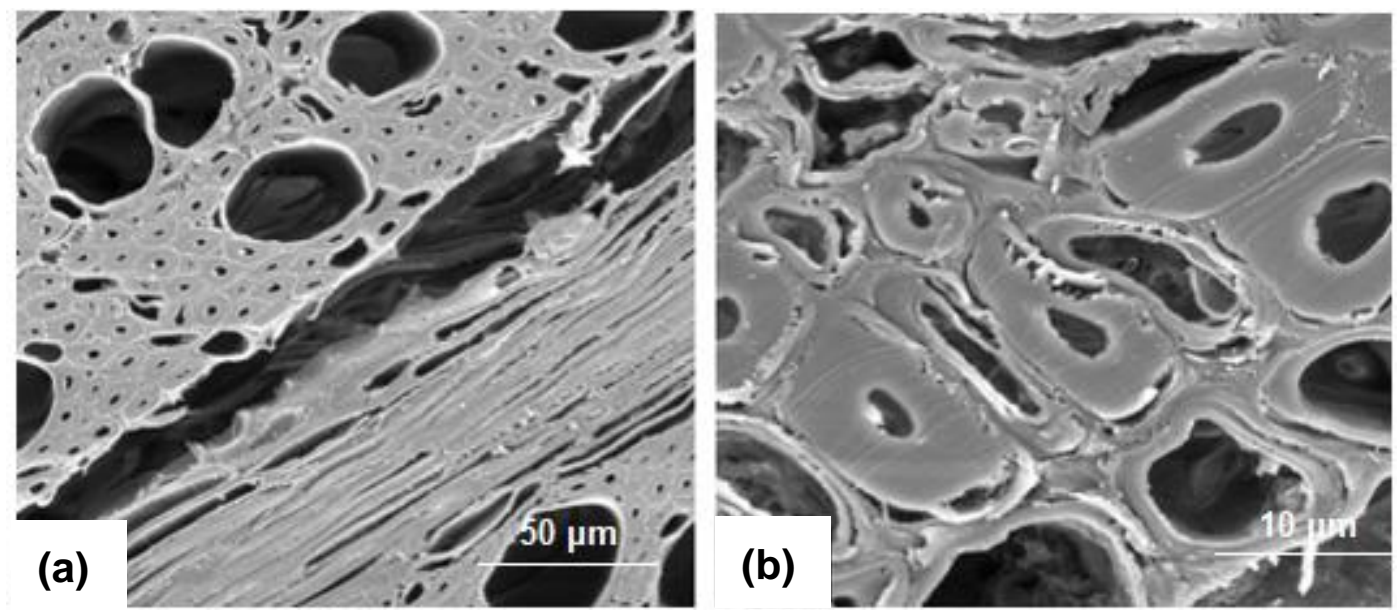

Fig. 8. Opposite wood at temperature $120^{\circ} \mathrm{C}: 50 \mu \mathrm{m}$ (a) and $10 \mu \mathrm{m}$ (b)

One possible explanation is that the G-layer shown in Fig. 7 was poorly developed. Okuyama et al. (1994), Fang et al. (2008), Vilkovská et al. (2018), and Kučerová et al. 
(2019) stated that the weakly developed reaction wood G-layer is less thick than the strongly developed reaction wood. Another characteristic of weakly developed reaction wood is that the G-layer is found only in some fibrous cells. The present observations are consistent with those of Vilkovská et al. (2018) and Gardiner et al. (2014), who reported that the thickness of the individual layers of the secondary wall varies from the middle to the ends of the fibrous cells as follows G-layer and layer $S_{2}$ become thinner, but the thickness of layer $S_{1}$ does not change. When analyzing the opposite wood (Fig. 8a, Fig. $8 \mathrm{~b}$ ), drying cracks were observed predominantly in the compound middle lamella at a drying temperature of $120^{\circ} \mathrm{C}$. At $60{ }^{\circ} \mathrm{C}$, these cracks were less pronounced.

\section{CONCLUSIONS}

1. Higher density values were observed in the oven-dry state for the reaction wood samples. Variability in density in a dry state can be caused by different quantitative and qualitative representations of thick-walled fibers with a gelatinous layer.

2. The differences in the drying time of the reaction wood and the opposite wood were most noticeable at a temperature of $60{ }^{\circ} \mathrm{C}$. The difference in drying time was $30 \mathrm{~h}$ and the reaction wood dried more slowly. The differences were equalized, and the drying end times were almost identical at $120^{\circ} \mathrm{C}$.

3. At $120{ }^{\circ} \mathrm{C}$, the reaction wood did not release the drying stresses into the compound middle lamella, but it did release them into the cell wall and the G-layer. The G-layer tore perpendicularly to the perimeter of the cell, which was reflected in the irregular shape of the lumen.

4. Opposite wood cell lumens retained their oval shape at temperatures above $100{ }^{\circ} \mathrm{C}$. The quality of the reaction wood was maintained.

5. The negative effect of higher temperature on the morphology of reaction wood and opposition wood was not confirmed.

\section{ACKNOWLEDGMENTS}

This work was supported by the Slovak Research and Development Agency under contract No. APVV-17-0583. This study also received funding from VEGA of the Ministry of Education, Science, Research and Sport of the Slovak Republic (No. 1/0729/18).

\section{REFERENCES CITED}

Araki, N., Fujita, M., Saiki, H., and Harada, H. (1983). "Transition of fibre wall structure from normal wood to tension wood in certain species having gelatinous fibres of S1+G and S1+S2+S3+G types," Mokuzai Gakkaishi 29(1), 267-273.

Clair, B., Alméras, T., Yamamoto, H., Okuyama, T., and Sugiyama, J. (2006). "Mechanical behaviour of cellulose microfibrils in tension wood, in relation with maturation stress generation," Biophysical Journal 91(3), 1128-1135. DOI:

10.1529/biophysj.105.078485

Clair, B., Ruelle, J., and Thibaut, B. (2003). "Relationship between growth stress, mechano-physical properties and proportion of fibre with gelatinous layer in chestnut (Castanea sativa Mill.)," Holzforschung 57(1), 189-195. DOI: 10.1515/HF.2003.028 
Čunderlík, I., and Hudec, I. (2002). "Axial permeability of normal and tension beech wood," in: Wood Structure and Properties 2002, J. Kúdela, and S. Kurjatko (eds.), Arbora Publishers, Zvolen, Slovakia, pp. 201-208.

Čunderlík, I., Kúdela, J., and Bluskova, G. (1995). "Relaxation of stresses in steamed beech tension wood," in: Lesotechnicesko Obrazovanie v Bulgarii [Forestry Education in Bulgaria], Sofia, Bulgaria, pp. 199-205.

Čunderlík, I. (1997). "Relaxation of growth stresses in tension beech wood during steaming and drying," in: Medzinárodná Vedecká Konferenica Les-Drevo-Životné Prostredie 1997 [International Scientific Conference on Forests, Wood, and the Environment 1997], Technical University of Zvolene, Zvolene, Slovakia, pp. 115120.

Fang, C.-H., Guibal, D., Clair, B., Gril, J., Liu, Y. M., and Liu, S.-Q. (2008). "Relationships between growth stress and wood properties in poplar I-69 (Populus deltoides Bartr. cv. "Lux" ex I-69/55)," Annals of Forest Science 65(3), Article number 307. DOI: 10.1051/forest:2008008

Gardiner, B., Barnett, J., Saranpää, P. and Gril, J. (2014). The Biology of Reaction Wood, Springer-Verlag Berlin Heidelberg, Berlin, Germany.

Kampf, R., Lorincová, S., Hitka, M., and Stopka, O. (2017). "Generational differences in the perception of corporate culture in European transport enterprises," Sustainability 9(9), Article number 1561. DOI: 10.3390/su9091561

Kučerová, V., Lagaňa, R., and Hýrošová, T. (2019). "Changes in chemical and optical properties of silver fir (Abies alba L.) wood due to thermal treatment," Journal of Wood Science 65(1), Article number 21. DOI: 10.1186s10086-019-1800-x

Kúdela, J., and Čunderlík, I. (2012). Bukové Drevo - Štruktúra, Vlastnosti, Použitie [Beech Wood Structure, Properties, and Use], Technical University in Zvolen, Zvolen, Slovakia, pp. 152-167.

Meloche, C. G., Knox, J. P., and Vaughn, K. C. (2006). "A cortical band of gelatinous fibers causes the coiling of redvine tendrils: A model based upon cytochemical and immunocytochemical studies," Planta 225(2), 485-498. DOI: 10.1007/s00425-0060363-4

Norberg, P. H., and Meier, H. (1966). "Physical and chemical properties of the gelatinous layer in tension wood fibres of aspen (Populus tremula L.)," Holzforschung 20(6) 174-178. DOI: 10.1515/hfsg.1966.20.6.174

Okuyama, T., Yamamoto, H., Yoshida, M., Hattori, Y., and Archer, R. R. (1994). "Growth stresses in tension wood: Role of microfibrils and lignification," Annals of Forests Science 51(3), 291-300. DOI: 10.1051/forest:19940308

Placet, V., Passard, J., and Perré, P. (2006). "Viscoelastic properties of green wood across the grain measured by harmonic tests: Hardwood $v s$. softwood and normal wood $v s$. reaction wood," Holzforschung 61(5), 548-557. DOI: 10.1515/HF.2007.093

Pilate, G., Chabbert, B., Cathala, B., Yoshinaga, A., Leplé, J.-C., Laurans, F., Lapierre, C., and Ruel, K. (2004). "Lignification et bois de tension [Lignification and tension wood]," Comptes Rendus Biologies 327(9-10), 889-901.

Reinprecht, L. (2016). Wood Deterioration, Protection and Maintenance, John Wiley \& Sons, Chichester, England.

STN 490108 (1993). "Wood. Determination of density,” Slovak Standards Institute, Bratislava, Slovakia.

STN 490103 (1993). "Wood. Determination of the moisture content of the physical and mechanical testing," Slovak Standards Institute, Bratislava, Slovakia.

Tarmian, A., Remond, R., Dashti, H., and Perré, P. (2012). "Moisture diffusion coefficient of reaction woods: Compression wood of (Picea abies L.) and tension 
wood of (Fagus sylvatica L.)," Wood Science and Technology 46(1), 405-417. DOI: 10.1007/s00226-011-0413-3

Vilkovský, P., and Čunderlík, I. (2017). "Structure of phloem and wood/bark shear strength of the sessile oak during dormant and growing period," Acta Facultatis Xylologiae Zvolen 59(1), 17-26. DOI: 10.17423/afx.2017.59.1.02

Vilkovska, T., Klement, I., and Výbohova, E. (2018). "The effect of tension wood on the selected physical properties and chemical composition of beech wood (Fagus sylvatica L.)," Acta Facultatis Xylologiae Zvolen 60(1), 31-40. DOI: 10.17423/afx.2018.60.1.04

Article submitted: February 26, 2020; Peer review completed: April 18, 2020; Revised version received and accepted: April 22, 2020; Published: April 27, 2020.

DOI: $10.15376 /$ biores. 15.2.4407-4416 